\title{
DEKOLONISASI DAN INDEGENISASI ILMU PEMERINTAHAN
}

\author{
Andi Luhur Prianto dan Abdillah \\ Program Studi Ilmu Pemerintahan Fakultas Ilmu Sosial dan Ilmu Politik, \\ Universitas Muhammadiyah Makassar \\ email: luhur@unismuh.ac.id
}

\begin{abstract}
ABSTRAK
Sindrom pasca-kolonial sulit dilepaskan pada negara-negara berkembang. Hampir semua bidang kehidupan masih terkoneksi dengan praktik-praktik kolonialisasi, tak terkecuali perkembangan Ilmu Pemerintahan. Perkembangan modernitas dan globalisasi pada dunia ketiga semakin membuat teori-teori ilmu sosial lokal menjadi terpinggirkan. Perkembangan Ilmu Pemerintahan tidak cukup mampu menjelaskan arah perkembangan global dan menjawab problematika lokal, secara akademis dan praktis. Seperti pada penggunaan konsepsi Ilmu Pemerintahan dari perspektif bestuurskunde, American politics, dan good governance adalah contoh formula peradaban barat, yang ditransmisikan dalam bentuk kolonialisme akademik. Eksistensi Ilmu Pemerintahan secara akademik dan praktis penting untuk mentransformasi model kearifan lokal sebagai perspektif baru. Kearifan ilmiah sebagai sumber inspirasi Ilmu pemerintahan secara akademis dan praktis harus dibebaskan dan dipribumisasi dalam menjawab problematika pemerintahan. Metode penelitian bersifat deskriptif kualitatif dengan pendekatan dekolonisasi. Teknik pengolahan data melalui dialektika pragmatik, dengan memformulasikan sintesis keilmuan baru. Hasil studi ini menegaskan bahwa Ilmu Pemerintahan sebagai pengetahuan pembebasan harus ditransformasi dari semangat liberasi (dekolonisasi) menuju diskursus ilmiah khas kearifan lokal keindonesiaan (indigenisasi). Kearifan lokal keindonesiaan seperti konsepsi Wanua di Soppeng, Sulawesi Selatan, dan Pamong Praja-Birokrasi Jawa, Budaya Politik BugisMakassar, sampai model kebijakan Kerajaan Mataram Islam adalah wujud keilmuan pemerintahan Indonesia sebagai khazanah kearifan ilmiah. Strategi dekolonisasi dan indegenisasi Ilmu Pemerintahan, dibutuhkan untuk menjelaskan problematika kepemerintahan yang tidak dapat dijelaskan keilmuan lain. Karena Ilmu Pemerintahan bukan sekedar untuk meningkatkan keterampilan pejabat pemerintah atau untuk menginspirasi praktik-praktik pelayanan pemerintahan, tetapi juga untuk membangun tradisi politik dan birokrasi yang berbasis pada realitas sosialnya.
\end{abstract}

Kata Kunci: dekolonisasi, indigenisasi, Ilmu Pemerintahan, kearifan ilmiah

\begin{abstract}
The post-colonialism syndrome is very difficult to remove in developing countries. Almost all areas of life are still connected with colonialization practices, including the development of science. The development of modernity and globalization in the third world has increasingly marginalized lokal social science theories. The development of science is not sufficient to explain the direction of global development and answer lokal problems, academically and practically. As in the use of the concept of government science from the perspective of bestuurskunde, American politics, and good
\end{abstract}


governance is such formula of western civilization, which is transmitted in the form of academic colonialism. The existence of government science academically and practically is important to transform lokal wisdom models into new perspectives. Scientific wisdom as a source of inspiration for government science academically and practically must be decolonialization and indigenization in answering governance problems. The research method is descriptive qualitative with a decolonialization approach. Data processing techniques through pragmatic dialectics, by formulating new scientific syntheses. The results of this study emphasize that the science of government as knowledge of liberation must be transformed from a spirit of liberation (decolonialization) to a scientific discourse typical of Indonesian lokal wisdom (indigenization). Indonesian lokal wisdoms such as the concept of Wanua in Soppeng, South Sulawesi, and the Civil Service of the Javanese Bureaucracy, Bugis-Makassar Political Culture, to the policy model of the Islamic Mataram Kingdom are the scientific manifestations of Indonesian government as a treasure trove of scientific wisdom. The strategy of decolonialization and indigenization of government science is needed to explain governance problems that cannot be explained by other scholars. Because the science of government is not just to improve the skills of government officials or to inspire government service practices, but also to build political and bureaucratic traditions based on their social reality.

Keywords: decolonization, indegenousization, governmental science, scientific wisdom

\section{Informasi Artikel}

Diterima: Oktober 2020, Disetujui: November 2020, Dipublikasikan: Desember 2020

DOI: https://doi.org/10.47431/governabilitas.v1i2.86

\section{PENDAHULUAN}

Pada situasi pasca-kolonalisme, perkembangan ilmu-ilmu sosial-humaniora mengalami kemerosotan dan terpinggirkan. Hal itu terjadi karena penetrasi modernitas dan globalisasi yang membuat ruang hidup dan pengembangan pengetahuan lokal semakin sempit. Ilmu Pemerintahan lokal dianggap tidak mampu menjawab masalah-masalah lokal dan global dalam realitas sosial. Untuk menjawab permasalahan itu, maka langkah pertama

yang harus dikembangkan adalah perspektif dekolonisasi dan indegenisasi, sebagai upaya memerdekakan diri dari kolonialisme akademik (Ashcroft et al., 2007). Sebuah buku yang berjudul "Sebuah Wacana Alternatif dalam Ilmu Sosial Asia" oleh Syed Farid Alatas (2010), mendeklarasikan semangat dekolonisasi Ilmu Pemerintahan. Kolonialisme akademis adalah fenomena yang setara dengan penjajahan ekonomi dan politik. Oleh karena itu, kita perlu bekerja keras untuk membebaskan diri dari belenggu penjajahan. Dunia akademis yang terjajah adalah ketika negara-negara kolonial mencoba untuk mengontrol ilmu di wilayah jajahannya. Mereka menciptakan struktur ketergantungan akademis dan mencoba 
memonopoli penyebaran ide-ide ilmiah, yang tentu saja disukai oleh penjajah berkepentingan (Alatas, 2010).

Apa yang dikatakan Taufik Abdullah (1984) sebenarnya bertepatan dengan dialog yang berlangsung pada Simposium UNESCO dan United Nations Asian Development Institute pada 1980-an. Bahaya kolonialisme akademis; sebagai kebutuhan untuk melepaskan gagasan atau ide dari penjara yang didirikan dan ditujukan pada dunia ketiga (termasuk Indonesia). Sejalan dengan pendapat tersebut, Soedjatmoko (1980) menyatakan kemiskinan pemahaman kita tentang keragaman kearifan lokal kita sendiri dan pemahaman kita yang masih bodoh tentang struktur sosial dan budaya kita membuat negara kita buruk dan terbatas, padahal Indonesia kaya akan khazanah keilmuan kearifan ilmiah untuk memjawab problematika keilmuan terutama problemtika perdebatan Ilmu Pemerintahan di Indonesia.

Dalam kategori ini, penjajahan pengetahuan melalui diskursus keilmuan di bidang Ilmu Pemerintahan harus memberi ruang pada anti-tesis keilmuan. Anti tesis tersebut berupa memunculkan keilmuan yang berbasis kearifan lokal ilmiah, dalam upaya dekolonisasi dan indigenisasi Ilmu Pemerintahan sebagai ilmu khas nusantara keindonesiaan, yang tidak dikenal dibelahan dunia lain (Yunanto, 2020). Secara umum, konsep Ilmu Pemerintahan jika dilihat dari tradisi Anglo Saxon berasal dari konsep pemerintah, dan konsep pemerintahan berasal dari tradisi hukum Eropa Kontinental. Sementara bestuurskunde adalah warisan kolonial Belanda, yang dari negara asalnya disebut administrasi. Pengetahuan tersebut dimonopoli untuk menjaga law and order sebagai warisan dari beamtenstaat kolonial, dengan niat hegemoni dan upaya memonopoli wajah keilmuan di Indonesia (Yunanto, 2020).

Dari perspektif semacam itu, situasi perkembangan Ilmu Pemerintahan di Indonesia tidak terlepas dari bahaya kolonialisme akademis. Terdapat hasrat untuk terlepas dari konstruksi pemikiran yang dibuat untuk dunia ketiga, khususnya di Indonesia. Oleh karena itu, perlu upaya dekolonisasi dan indegenisasi (pribumisasi) konsep dan teori-teori pada perspektif Ilmu Pemerintahan khas Indonesia (kearifan lokal), yang diharapkan bisa dirasakan dan berkontribusi lebih nyata untuk memperkuat eksistensinya sebagai ilmu (Kuntjoro, 1984; Abdullah, 1984).

Tulisan ini berfokus kepada masalah dekolonisasi (semangat pembebasan) dan indigenisasi (pribumisasi) Ilmu Pemerintahan sebagai bangunan prespektif Ilmu Pemerintahan berbasis kearifan lokal keindonesiaan. Dalam tinjauan kolonialisasi secara 
akademik dan praktis, Ilmu Pemerintahan yang telah banyak dipraktikkan di Indonesia saat ini, seperti konsepsi bestuurskunde (Belanda) untuk pendidikan keterampilan para birokrat yang mengisi kepemimpinan pemerintahan di daerah-daerah (Yunanto, 2020), American politics dalam hubungan kekuasaan pemerintah dan yang diperintah (Supriatman, 2003), sampai pada konsepsi good governance tata pemerintahan neo-liberal (Prianto, 2011). Semua konsepsi itu berasal dari perkembangan peradaban dan Ilmu Pemerintahan dunia barat dan tidak berpijak pada praktik ke-pemerintahan Indoensia yang memiliki kearifan lokalnya sendiri. Oleh karena itu, tulisan ini bermaksud untuk menjawab realitas problematika Ilmu Pemerintahan di Indonesia, sekaligus juga memperkuat eksistensi Ilmu Pemerintahan dalam lingkungan ilmu sosial dan ilmu politik.

Metode penelitian dalam penelitian ini adalah metode deskriptif kualitatif yaitu sebagai penjabaran melalui kata-kata (Creswell, 2012), dengan pendekatan dekolonisasi sebagai semangat pembebasan dari dominasi keilmuan barat (Smith, 2005), yang bersifat dialektika pragmatik yaitu melihat sintesis keilmuan. Dalam menguji keabsahan data peneliti menggunakan triangulasi sumber dengan menyesuaikan Metodologi Ilmu Pemerintahan menyangkut pengumpulan, analisa, evaluasi dan pemakaian data (Haboddin et al., 2016).

\section{NARASI INDIGENOUS ILMU PEMERINTAHAN}

Istilah indigenous knowledge dan istilah indigenization dipakai dalam kerangka yang hampir senada meskipun dalam perspektif yang lain. Secara etimologis, indigenisasi senada dengan istilah pribumisasi atau domestikasi. Terminologi indigenisasi memiliki bermacammacam makna. Apabila ditinjau dari aspek sosiologi pengetahuan, indigenisasi memiliki makna beragam di berbagai negara satu sama lain. Istilah indigenisasi hadir dan berkembang, terutama di bekas negara jajahan kolonial Barat seperti di Indonesia (Sudrajat \& Nasiwan, 2017). Terminologi indigenous knowledge yang digunakan oleh banyak kajian tentang pengelolaan sumber daya alam berbasis masyarakat, diartikan sebagai pengetahuan yang diwariskan serta dan perilaku secara turun-temurun terkait dengan kebudayan. Biasanya pengetahuan semacam ini dikembangkan di lingkungan lokal, dan sangat ditentukan oleh minat dan keadaan warga setempat. Pengetahuan ini terus berkembang dari waktu ke waktu. Pengetahuan ini dikembangkan berdasarkan pengalaman dan terus diterapkan bahkan selama berabad-abad, sejalan dengan budaya lokal, dan selalu dalam kondisi yang dinamis dan terus 
berubah (Langill \& Landon, 1998). Sebagai contoh, di Filipina terdapat dua alasan untuk indigenisasi, pertama; perlu dikembangkan teori dan metode yang lebih cepat untuk memahami masyarakat Filipina dan memecahkan masalah sosial, khususnya di tingkat komunitas-komunitas. Kedua, dijelaskan sebagai bentukan teori dan "metode asli" atau metodologi pada ilmu sosial khas Filipina (Cynthia \& Bautista, 1997). Hal ini bisa menjadi "pintu masuk" bahwa upaya indegenisasi tidak hanya berhenti pada tataran pengertian teoritis, namun juga masuk dalam tataran metodologis (Santoso \& Santoso, 2003).

Di Malaysia, istilah aboriginalisasi ditemukan dalam gerakan "domestikasi", yang bertujuan untuk "menjinakkan" ilmu-ilmu sosial, khususnya bidang antropologi dan sosiologi. Menjinakkan dengan cara mengaturnya ke dalam studi lapangan atau studi antropologi dengan pola etnik. Kasus lokalisasi ilmu di Malaysia menunjukkan bahwa intervensi politik berpengaruh besar terhadap kebijakan pembangunan ilmu sosial (Sudrajat \& Nasiwan, 2017: 14). Berangkat dari semangat yang sama, dalam indigenisasi Ilmu Pemerintahan dan dekolonisasi pengetahuan di Indonesia yang harus berubah, kebanggaan dengan menggunakan konsepsi dan teori-teori barat harus berakhir.

Dialektika keilmuan harus memanfaatkan sumber daya keilmuan berbasis kearifan lokal, termasuk tentang Ilmu-ilmu Pemerintahan keindonesiaan. Advokasi keilmuan berbasis pengetahuan lokal pada akhirnya akan menjadi sebuah kebanggaan bangsa secara kolektif. Indeginisasi keilmuan secara bersama-sama dengan bidang keilmuan lain, akan membangun kemandirian konsepsi teori khas keindonesiaan, seperti hasil dari upaya Ilmu Pemerintahan untuk terlepas dari belenggu kolonialisasi akademik.

\section{PERKEMBANGAN KONSEP PEMERINTAHAN: KOLONISASI AKADEMIK}

Pada awalnya pemerintahan dibentuk untuk menghindari kebingungan yang disebabkan oleh kepentingan pribadi yang saling berhadapan dalam ruang dan waktu tertentu. Keadaan ini memaksa lahirnya seseorang yang berpengaruh, sehingga membentuk kelompok yang paling kuat dalam upaya mendamaikan dan melindungi individu maupun kelompok dari campur tangan pihak lain. Dalam perkembangannya, mereka memiliki hak istimewa untuk melakukan apapun, dalam rangka menjamin perlindungan dan keselamatan. Kelompok ini adalah minoritas, memiliki kekuasaan yang relatif tidak terbatas, dapat 
mewakili kelompok mayoritas (rakyat), bahkan dapat membentuk kebijakan sesuai dengan keinginannya sendiri itulah yang disebut pemerintahan (Labolo, 2013).

Mereka secara sadar mengklaim bahwa mereka adalah satu-satunya entitas dengan otoritas tertinggi, sehingga mereka dengan senang hati disebut sebagai pemerintah. Selain itu, untuk alasan apapun, gangguan yang ada harus dihilangkan. Dengan segala klaim atribut, pemerintah diartikan sebagai sekelompok orang yang bertanggung jawab atas penggunaan kekuasaan (Labolo, 2013). Hal yang serupa dengan konsep C.F. Strong tentang kekuatan militer, pemerintahan yang selalu terkait dengan organisasi angkatan bersenjata, tetapi satu atau dua dari banyak orang dalam organisasi tersebut bersiap untuk mencapai tujuan bersama dari urusan publik. Kelompok tersebut cukup untuk disebut kekuatan organisasi (pemerintahan) (Wilson, 1903). Perspektif dominan dalam mendefnisikan pemerintahan sebagai unit paling umum yang mengemban tanggung jawab tertentu untuk memelihara sistem dan menjalankan monopoli yang sebenarnya melalui kekuatan koersif. Pemerintahan dilihat sebagai gejala kekuasaan, sehingga pemerintah dipandang sebagai pemegang monopoli hukum untuk mengintervensi sebagai bentuk pertanggungjawaban untuk kepentingan umum demi memelihara sistem yang dibangun bersama (Apter, 1965).

Dalam pandangan yang lebih sederhana melihat pemerintahan, seperti mengandaikan lembaga keluarga menjadi pemerintahan mikro. Iver (1947) melihat pemerintah sebagai sekelompok organisasi dengan kekuasaan yang melaluinya orang dapat diatur. Bahkan, dia juga melihat pemerintah sebagai perusahaan besar dari semua perusahaan ketenagakerjaan yang ada. Lebih lanjut Mac Iver (1947) mengatakan keluarga sebagai unit terkecil yang merupakan fenomena yang tepat untuk melihat gejala pemerintahan secara luas, di mana kepala pemerintahannya adalah sang ayah yang memiliki otoritas membuat, menerapkan, dan mengawasi jalannya kebijakan. Sang ibu sebagai kepala keuangan, perbendaharaan, penganggaran, sekaligus penasihat. Sang ayah selaku pelaksana kebijakan dan sang anak sebagai objek kebijakan yang berbasis kepatuhan dan ketaatan dari kebijakan ayah dan ibu selaku kepala pemerintahan, hubungan dari ketiga entitas tersebut sebagai objek kajian Ilmu Pemerintahan.

Dengan sentuhan modernitas dan westernitas, konsepsi pemerintahan pun berkembang. Konsep-konsep klasik yang pada mulanya diintroduksikan melalui birokrasi kolonial, mengalami fase perkembangan semakin kompleks. Kompleksitas itu kemudian 
diinstitusionalisasi melalui pengembangan secara praktis dan akademis. Dalam ranah akademik, pengembangan keilmuan pemerintahan bertransformasi; dari konsep government, governance hingga digital governance. Perubahan konsep tersebut mewakili praktik perubahan setting ideologi politik dominan. Ketika masa penjajahan kolonial hingga pascakemerdekaan, pemerintah diidentifikasi sebagai aktor dominan dalam pengelolaan kekuasaan yang berpusat pada negara. Konsepsi ini setidaknya bertahan dari zaman kolonial, pascakemerdekaan hingga di bawah naungan otoritarianisme Orde Baru. Dalam fase setelah reformasi politik 1998, konsep pemerintahan mulai bergeser ke pendulum governance. Konsepsi governance, yang diperhalus dengan istilah good governance, sebagai anti-tesis dari government yang dianggap bad-governance. Konsep governance pun didiseminasikan melalui lembaga-lembaga akademik dan menjadi arus utama pembelajaran di bidang pemerintahan. Padahal sesungguhnya gagasan ini bukanlah "resep mujarab" yang bebas nilai. Rezim good governance telah memfasilitasi bekerjanya mekanisme neo-liberal dalam tata pemerintahan. Semua tidak lepas kepentingan para pemberi bantuan (Prianto, 2011; Prianto, 2014). Pada tahap berikutnya perubahan konsep governance secara ditingkatkan seiring migrasi interaksi ke ruang digital. Digitalisasi pemerintahan seiring dengan arah revolusi industri generasi keempat. Digital governance menjadi platform utama kebijakan dan pelayanan publik baru (Denhardt \& Denhardt, 2003). Meskipun di tingkat lokal, konsep digitalisasi ini tidak dilakukan dengan pra-kondisi yang memadai, terutama kesiapan infrastruktur dan literasi teknologi informasi.

Tabel 1. Perkembangan Konsepsi Pemerintahan

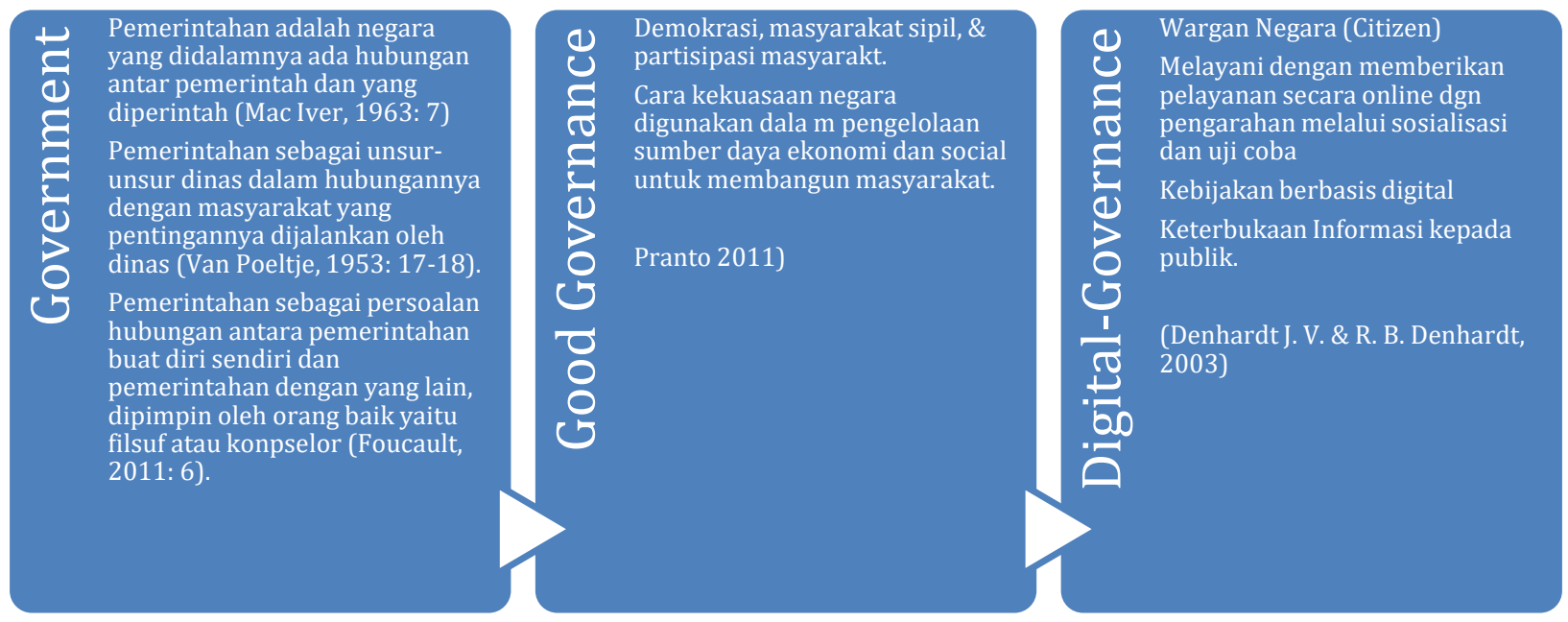

Sumber: Olahan penulis dari berbagai sumber, 2020 
Pada Tabel No. 1 ini, perkembangan pemerintahan dalam wujud hegemoni dan kolonialisasi secara akademik maupun praktis dapat dijelaskan. Pertama, pemerintahan sebagai government yaitu pemerintahan sebagai negara yang di dalamnya ada hubungan antara pemerintah dan yang diperintah (Iver, 1947). Sejalan dengan perspektif Van Poeltje (1953) bahwa pemerintahan terdiri dari unsur-unsur dinas dalam hubungannya dengan masyarakat yang kepentingannya dijalankan oleh dinas, dan serta Foucault (2011) yang memandang pemerintahan sebagai persoalan hubungan antara pemerintahan dengan diri sendiri dan pemerintahan dengan pihak yang lain. Dalam perkembangan kedua dari konsepsi government ke good governance diartikan oleh Prianto $(2011,2014)$, yaitu pemerintahan sebagai arena demokrasi, masyarakat sipil, \& partisipasi masyarakat, serta cara kekuasaan negara digunakan dalam pengelolaan sumber daya ekonomi dan sosial untuk membangun masyarakat. Dan perkembangan selanjutnya, konsep pemerintahan generasi ketiga memandang pemerintahan di era revolusi industri 4.0, pemerintahan dilihat dalam konsepsi digital governance (Denhardt \& Denhardt, 2003). Kita tahu dominasi dan hegemoni perkembangan konsepsi pemerintahan ini berasal dari tradisi dan perkembangan peradaban barat. Kolonialisasi keilmuan secara akademik dan praktis, masih mewarnai dinamika kepemerintahan Indonesia saat ini. Untuk itulah, perspektif indegenisasi diharapkan melahirkan jawaban atas problematika kepemerintahan yang tidak berjarak dengan realitas sosial keindonesiaan.

\section{KEARIFAN LOKAL DAN TRADISI-TRADISI PEMERINTAHAN DI NUSANTARA}

Kearifan lokal Indonesia seperti Tomanurung di Soppeng, Subak di Bali, Pahomba di Nusa Tenggara Timur dan Pamong Praja - Birokarasi Jawa, berhasil membimbing masyarakat dan lingkungan sekitarnya. Manusia, komunitas dan masyarakat serta lingkungan mencapai hubungan yang seimbang dan harmonis. Masyarakat di Indonesia sebagian besar memiliki warisan nenek-moyang yakni kearifan lokal, baik berupa nilai, norma, etika, kepercayaan, adat istiadat, hukum adat, dan aturan-aturan khusus yang beragam dalam rangka menjaga keseimbangan alam (Hastuti, 2017). Ada masyarakat di lereng Gunung Merapi di Yogyakarta melakukan ritual labuhan di Merapi secara berkala, yang diwariskan dari generasi ke generasi yang diyakini melindungi adat dan lingkungan mereka di mana Lereng Merapi menjadi zona penyangga. Di tengah hiruk pikuk dinamika Ilmu Pemerintahan saat ini, muncul kesadaran yang diawali dari diskursus-diskursus yang dikembangkan para 
ilmuan dan peneliti Ilmu Pemerintahan guna mengkonstruksi ulang ilmu sosial keindonesiaan berbasis kearifan pengetahuan lokal, khususnya Ilmu Pemerintahan yang ada di dunia akademik.

Tabel 2. Bentuk Kearifan Lokal dan Tradisi Pemerintahan Khas Keindonesiaan

\begin{tabular}{|c|c|c|c|}
\hline KERAJAAN & Bentuk Pemerintahan & Gaya Pemerintahan & $\begin{array}{c}\text { Makna } \\
\text { Pemerintahan }\end{array}$ \\
\hline $\begin{array}{l}\text { Wanua } \\
\text { (Kerajaan) } \\
\text { Soppeng } \\
\text { (Kila et al., } \\
\text { 2018) }\end{array}$ & 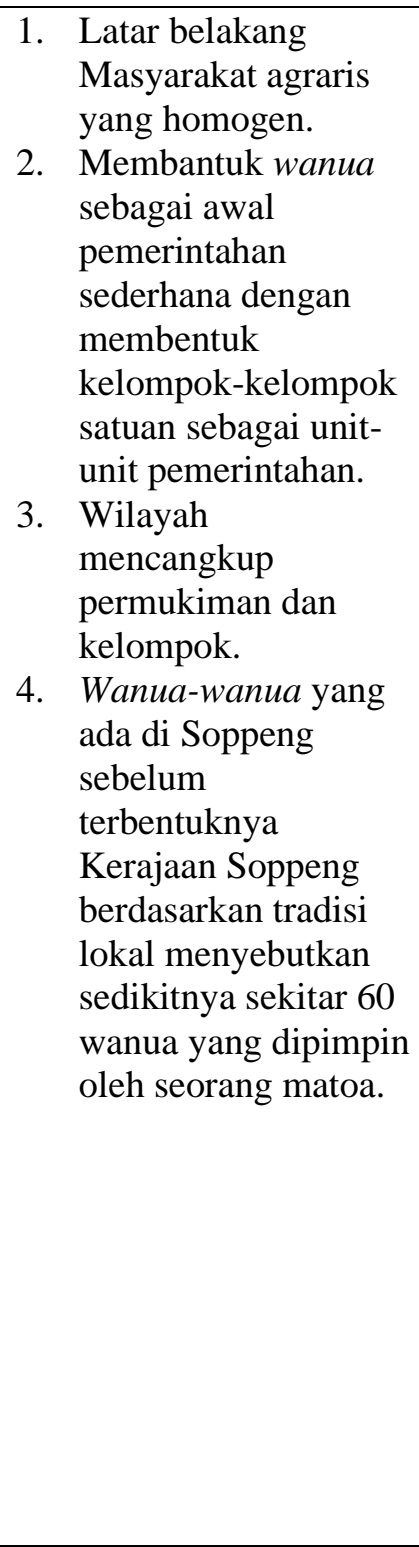 & $\begin{array}{l}\text { 1. } 60 \text { matoa } \\
\text { (pemerintah) yang } \\
\text { pernah memerintah, } \\
\text { mereka berdiri } \\
\text { sendiri dan } \\
\text { aturannya hanya } \\
\text { berlaku untuk } \\
\text { kelompoknya } \\
\text { sendiri. Apabila } \\
\text { antara satu Matoa } \\
\text { dan Matoa lain tidak } \\
\text { tersinergi sehingga } \\
\text { terjadi } \\
\text { ketidakseimbangan } \\
\text { kehidupan karena } \\
\text { yang kuat, di mana } \\
\text { pihak yang kuat } \\
\text { akan menguasai } \\
\text { yang lemah atau } \\
\text { istilah politiknya } \\
\text { sianre bale taue. } \\
\text { Konsep } \\
\text { Tomanurung } \\
\text { sebagai solusi baru } \\
\text { (Pemerintahan) } \\
\text { dalam kekacauan } \\
\text { yang terjadi } \\
\text { ditenggah } \\
\text { masyarakat. } \\
\text { Tomanurung } \\
\text { sebagai awal adanya } \\
\text { raja yang memulai } \\
\text { dan menyusun } \\
\text { pemerintahan gaya } \\
\text { baru. } \\
\end{array}$ & 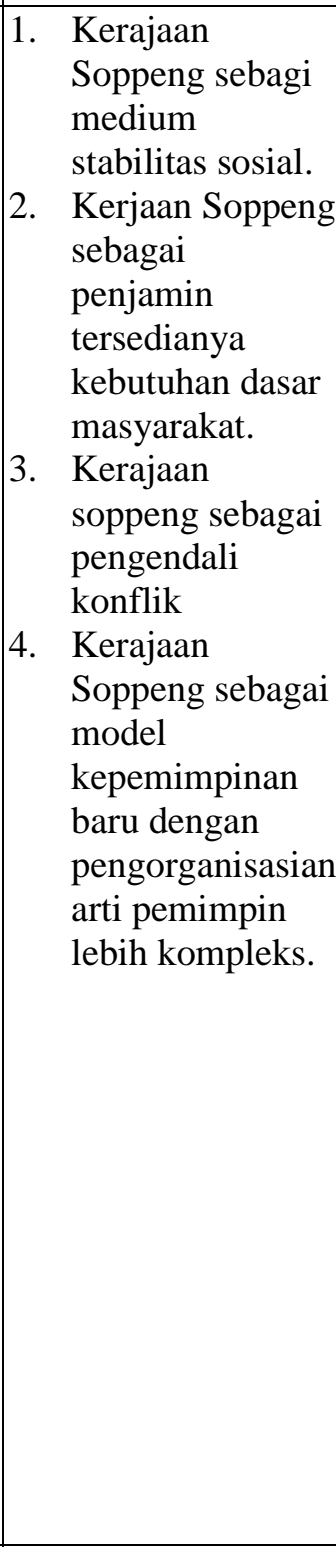 \\
\hline $\begin{array}{l}\text { (The Making of } \\
\text { Bureaucratic } \\
\text { Elit: The } \\
\text { Colonial } \\
\text { Transformation } \\
\text { of the Javanese }\end{array}$ & $\begin{array}{l}\text { 1. Pemimpin } \\
\text { Rakyat/pelayan } \\
\text { masyarakat/pegawai } \\
\text { rakyat sebagai } \\
\text { Pamong Praja. }\end{array}$ & $\begin{array}{l}\text { 1. Pemerintah (Pamong } \\
\text { praja-Birokrasi } \\
\text { Jawa) bertugas } \\
\text { melayani dan } \\
\text { memberikan } \\
\text { perlindungan. }\end{array}$ & $\begin{array}{l}\text { 1. Pamong sebagai } \\
\text { pelayan publik } \\
\text { agar mampu } \\
\text { men-ngemong } \\
\text { (melayani), } \\
\text { Ngomong }\end{array}$ \\
\hline
\end{tabular}




\begin{tabular}{|c|c|c|c|}
\hline KERAJAAN & Bentuk Pemerintahan & Gaya Pemerintahan & $\begin{array}{c}\text { Makna } \\
\text { Pemerintahan }\end{array}$ \\
\hline $\begin{array}{l}\text { Priyayi) Pamong } \\
\text { praja dalam } \\
\text { Birokrasi Jawa } \\
\text { (Sutherland: } \\
\text { 1979) }\end{array}$ & 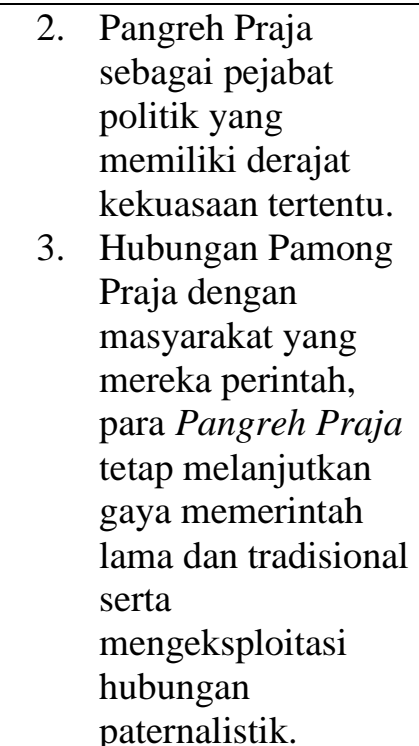 & \begin{tabular}{|ll} 
2. & Pemerintah Pegawai \\
& Kolonial (Pamong \\
& Praja) hanya dalam \\
& upaya menjaga \\
& stabilitas politik.
\end{tabular} & $\begin{array}{l}\text { (komunikasi), } \\
\text { di-omong } \\
\text { (dinilai). } \\
\text { 2. } \\
\text { Pemerintahan } \\
\text { (Pamong Praja- } \\
\text { Birokrasi Jawa) } \\
\text { dibentuk untuk } \\
\text { melayani rakyat } \\
\text { sebagaimana } \\
\text { mengasuh anak, } \\
\text { penuh } \\
\text { perlindungan, } \\
\text { dan kasih sayang } \\
\text { selama kapanpun }\end{array}$ \\
\hline $\begin{array}{l}\text { Budaya Politik } \\
\text { Bugis-Makassar } \\
\text { (Yani, 2007) }\end{array}$ & $\begin{array}{l}\text { 1. Budaya politik Orang } \\
\text { Bugis-Makassar yang } \\
\text { mewarnai semua } \\
\text { kerajaan atau sistem } \\
\text { pemerintahan di } \\
\text { Bugis dan Makassar } \\
\text { adalah Perjanjian } \\
\text { Politik antara } \\
\text { kelompok (anang) } \\
\text { dalam wilayah } \\
\text { permukiman masing- } \\
\text { masing. } \\
\text { Kontrak Politik untuk } \\
\text { melahirkan hukum } \\
\text { dan membangun } \\
\text { sistem hukum. } \\
\text { Kepemimpinan oleh } \\
\text { satu orang yang } \\
\text { dianggap mampu } \\
\text { mempersatuan dan } \\
\text { mengayomi } \\
\text { masyarakat. } \\
\text { Bentuk Pemerintahan } \\
\text { Bugis-Makassar } \\
\text { adalah Pemerintahan } \\
\text { Rakyat-Perwakilan } \\
\text { (Republik- } \\
\text { Demokrasi). }\end{array}$ & 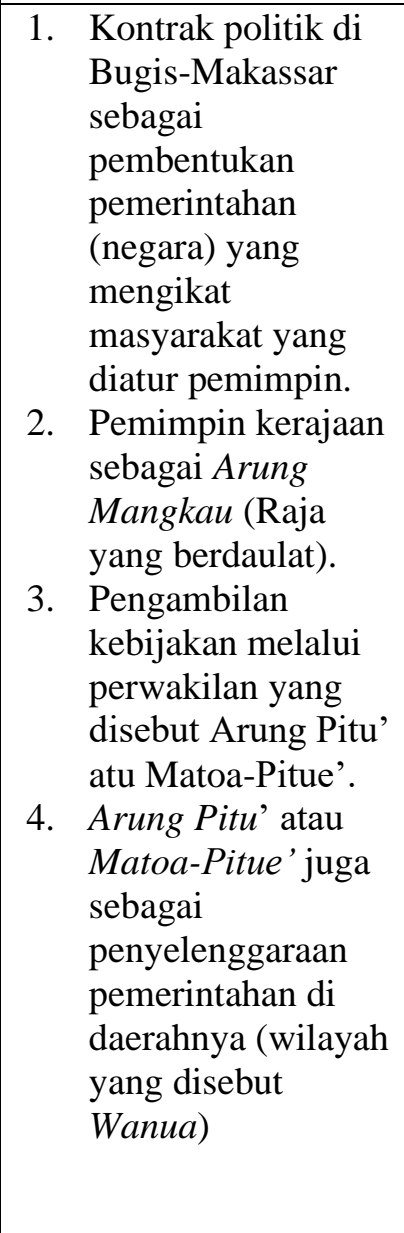 & 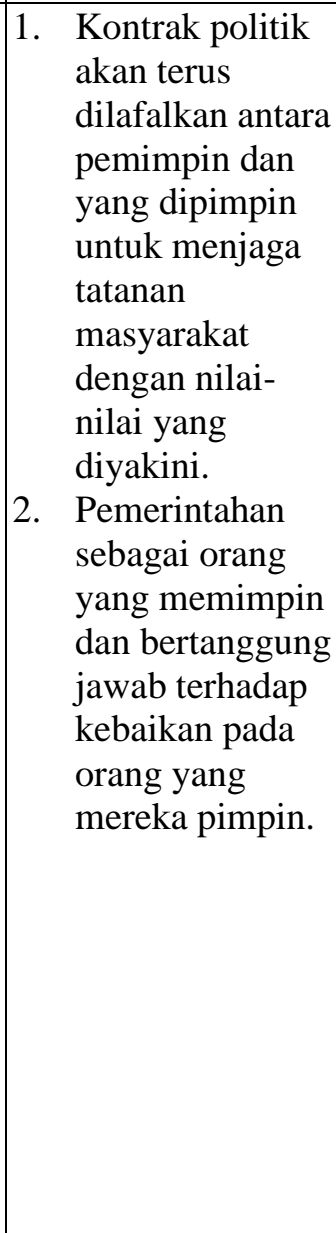 \\
\hline $\begin{array}{l}\text { Kebijakan } \\
\text { Politik dan } \\
\text { Sosial Ekonomi } \\
\text { Kerajaan }\end{array}$ & $\begin{array}{l}\text { 1. Sultan Agung selaku } \\
\text { pemimpin mataram } \\
\text { Islam memerintah } \\
\text { tahun } 1613-1646 \mathrm{M} \text {. }\end{array}$ & $\begin{array}{ll}\text { 1. } & \text { Pemimpin harus } \\
\text { tegas dan keras } \\
\text { namun bijaksana. }\end{array}$ & $\begin{array}{ll}\text { 1. } & \text { Islam sebagai } \\
\text { sistem nilai yang } \\
\text { dipegang teguh } \\
\text { dan diyakini }\end{array}$ \\
\hline
\end{tabular}




\begin{tabular}{|c|c|c|c|}
\hline KERAJAAN & Bentuk Pemerintahan & Gaya Pemerintahan & $\begin{array}{c}\text { Makna } \\
\text { Pemerintahan }\end{array}$ \\
\hline $\begin{array}{l}\text { Mataram Islam } \\
\text { Masa } \\
\text { Pemerintahan } \\
\text { Sultan Agung } \\
\text { (1613-1646) } \\
\text { (Harun, 1994) }\end{array}$ & 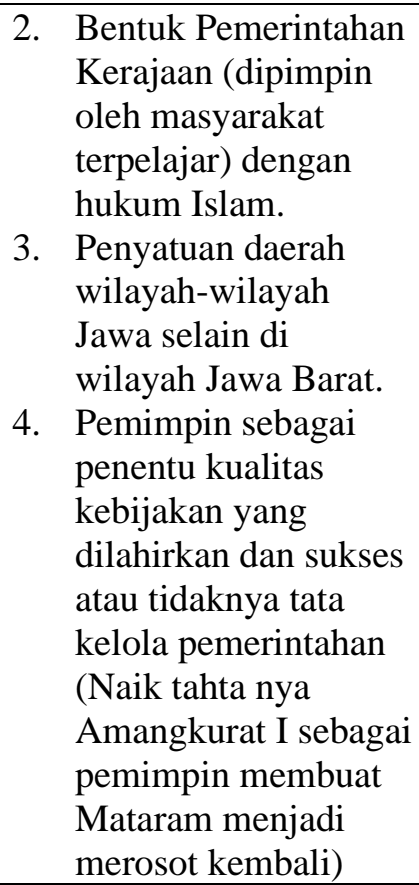 & 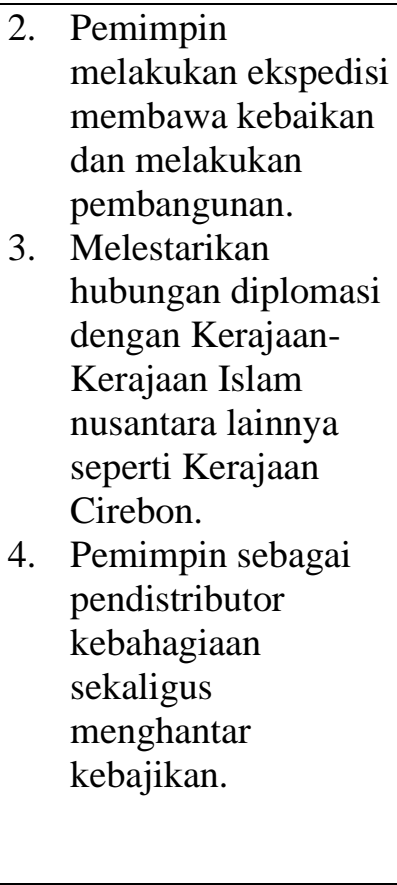 & $\begin{array}{l}\text { dalam prinsip } \\
\text { hidup. } \\
\text { 2. } \\
\text { Kebijakan yang } \\
\text { baik yang } \\
\text { bermanfaat } \\
\text { untuk orang } \\
\text { banyak. } \\
\text { 3. Kebaikan tidak } \\
\text { boleh dinikmati } \\
\text { sendiri, itu harus } \\
\text { di distribusikan } \\
\text { pada setiap } \\
\text { orang. }\end{array}$ \\
\hline
\end{tabular}

Sumber: Olahan peneliti, 2020

Pada Tabel 2 ini, memuat gagasan, konsepsi, dan teori kepemerintahan yang berbasis kearifan lokal tradisi keindonesiaan. Beberapa contoh seperti di Kerajaan Soppeng yang menjelaskan bahwa latar belakang lahirnya gejala pemerintahan pertama kali di Indonesia dari masyarakat agraris yang homogen. Komunitas kemudian membentuk Wanua sebagai awal pemerintahan sederhana dengan membentuk satuan kelompok-kelompok terkait sebagai unit-unit pemerintahan. Wilayahnya mencakup permukiman dan kelompoknya. Wапиа-Wапиа sudah ada di Soppeng sebelum terbentuknya Kerajaan Soppeng. Berdasarkan catatan sejarah lokal, disebutkan sedikitnya sekitar 60 betuk Wanиa yang dipimpin oleh seorang Matoa. Konstruksi ketatanegaraan tradisional ini menjadi awal terbangunnya sistem pemerintahan modern, seperti yang kita kenal saat ini selain sebagai organisasi pegawai publik dan pejabat politik. Selain kearifan lokal dan tradisi kepemerintahan di Soppeng yang memperkenalkan konsepsi pemerintahan Tomanurung, yang berbasis pemilihan dari 60 Wanua yang direpresentasi oleh para Matoa.

Di Jawa juga ada konsep pamong praja atau birokrasi berbasis kearifan lokal Indonesia. Pamong praja sebagai pelayan publik dituntut untuk mampu ngemong (melayani), ngomong (komunikasi), di-omong (dinilai). Pemerintahan (pamong raja-birokrasi Jawa) pun dibentuk 
untuk melayani rakyat. Pelayanan itu layaknya mengasuh anak yang penuh perlindungan dan kasih sayang, yang pada intinya adalah pemerintah (pamong praja-birokrasi Jawa) bertugas melayani dan memberikan perlindungan (Sutherland, 1979). Dalam konteks yang luas, budaya politik pemerintahan Bugis-Makassar juga memberi nilai tradisi dan kearifan yang berbeda. Corak pemerintahan yang berlaku adalah yang berbentuk kerajaan, dengan berbagai macam variasinya. Dalam sistem pemerintahan di Bugis dan Makassar, legitimasi kekuasaan lahir dari perjanjian politik atau kontrak sosial antar kelompok (Anang) dalam wilayah permukiman masing-masing. Kontrak Politik untuk melahirkan hukum dan membangun sistem hukum. Sistem kepemimpinan Bugis-Makassar dipimpin seorang yang dianggap mampu mempersatukan dan mengayomi masyarakat. Kemudian bentuk pemerintahan BugisMakassar adalah pemerintahan rakyat-perwakilan (republik demokrasi) (Yani, 2007).

Pada kearifan lokal masalah kebijakan politik, yang dalam formulasi kebijakannya sarat akan konflik (Prianto, 2014) dan sosial-ekonomi pemerintahan Indonesia bisa kita lihat pada masa Kerajaan Mataram Islam, dipimpin oleh Sultan Agung (Den Mas) selaku generasi ketiga pemimpin Kerajaan Mataram Islam memerintah tahun 1613-1646 M. Bentuk sistem pemerintahannya adalah Kerajaan (dipimpin oleh masyarakat terpelajar) sesuai dengan hukum Islam. Dalam kebijakan sosial ekonominya melakukan ekspedisi membawa kebaikan dan melaksanakan pembangunan pada daerah-daerah di Jawa. Selain prioritas penyatuan daerah wilayah-wilayah Jawa, kecuali di wilayah Jawa Barat, juga melakukan diplomasi pemerintahan dengan Kerajaan-kerajaan Islam seperti Kerajaan Cirebon. Pemimpin sebagai penentu kualitas kebijakan yang dilahirkan dan penentu sukses atau tidaknya tata kelola pemerintahan. Peristiwa naik tahtanya Amangkurat I sebagai pemimpin membuat Mataram menjadi merosot (Harun, 1994). Pembelajarannya kebijakan yang baik adalah kebijakan yang membawa kebaikan pada masyarakat.

Menurut Labolo (2013) upaya merajut Ilmu Pemerintahan dibangun pada 3 (tiga) tonggak utama. Istilah yang digunakan yaitu sub-kultur ekonomi, kekuasaan, dan sosial. Semakin kuat kualitas interaksi antar sub-kultur, mendorong suatu hubungan yang dapat bersifat asosiatif. Disinilah kualitas hubungan dari mereka yang memerintah maupun yang diperintah mengalami lonjakan, pada kualitas hubungan yang ideal. Sebaliknya, semakin lemah interaksi antar sub-kultur menciptakan suatu relasi yang bersifat disosiatif. Dalam hal ini, kualitas hubungan mereka yang diperintah maupun yang memerintah dapat mengalami 
kesenjangan yang tak diharapkan. Pada dasarnya, sub-kultur kekuasaan dan sub-kultur ekonomi adalah produk sub-kultur sosial. Maknanya, baik pemerintah maupun pemegang modal adalah hasil reproduksi masyarakat itu sendiri. Dari kerangka logika seperti itu, maka perspektif umumnya adalah pemerintahan diartikan sebagai dari rakyat, oleh rakyat, dan untuk rakyat. Sebuah konsep yang sudah dikenal sejak dahulu kala dalam kearifan lokal keindonesiaan. Maka Pemerintahan yang baik adalah pemerintahan yang berasal dari rakyat.

Gagasan, konsepsi, dan teori kepemerintahan yang berasal dari khazanah keilmuan kearifan lokal ilmiah yang ada di Indonesia, sebagai sebuah diskursus keilmuan yang diharapkan secara akademis dan praktis, menjadi jawaban dari problematika kepemerintahan. Masalah-masalah utama seperti masalah mental birokrasi yang gagal untuk menghadirkan tata pemerintahan yang baik, kita tahu sampai saat ini masih banyak terjadi pembajakan birokrasi untuk kepentingan elite. Kegagalan tujuan kebijakan-kebijakan politik yang tidak mampu membawa kesejahteraan karena hilangnya hakikat perjuangan kepada tujuan mulia politik yang sesungguhnya, dengan para aktor politik yang masih hanya mementingkan dirinya sendiri (Djati, 2013). Oleh karena itu nilai-nilai kearifan lokal seperti nilai dan tradisi kebersamaan, gotong royong, kepentingan kolektif, kesejahteraan, keadilan sosial dan keteladanan pemimpin yang jujur adalah sebuah jawaban atas problematik kepemerintahan yang terjadi selama ini. Formula konsepsional yang bersumber pada westernisasi dan globalisasi nilai-nilai kepemerintahan, sangat jauh berbeda dengan nilainilai yang sudah ada sejak lama dan mengakar dalam hidup dan kebiasaan masyarakat Indonesia. Sekaligus juga menunjukkan kegagalan dalam mengartikulasi dan mentransformasi khazanah kearifan lokal kita sendiri.

\section{KOLONISASI KE DEKOLONISASI: JALAN PEMBEBASAN ILMU PEMERINTAHAN KEINDONESIAAN}

Komitmen peneliti terhadap Ilmu Pemerintahan Indonesia harus melengkapi pengintegrasian realitas Indonesia terutama perspektif pemerintahan kearifan lokal keindonesiaan (Prianto, 2011). Body of knowledge Ilmu Pemerintahan khas Indonesia, setidaknya serius membahas hal-hal fundamental, yang menjadi dasar sebuah negara bangsa. Dalam konteks keindonesiaan, landasan ideologi "Pancasila" menjadi titik tolak bagi perkembangan Ilmu Pemerintahan yang melibatkan realitas Indonesia, sebagai kearifan lokal atau lokal wisdom keindonesiaan. Meskipun kini perspektif governance telah menjadi 
perspketif dominan yang mewarnai diskursus akademis dan praktis tentang Ilmu Pemerintahan. Pendekatan good governance makin populer setelah The Word Bank (TWB) menetapkannya sebagai salah satu kerangka berfikir resmi dalam aktivitas tata kelola pemerintahan. Governance menjadi semakin berkembang dan tidak terbatas hanya menyangkut isu-isu manajerial-administratif, seperti birokrasi, analisis kebijakan, efisiensi pelayanan publik. Kehadiran governance ini pada gilirannya akan melanggengkan pendekatan barat yang selama ini ada (Savirani, 2003).

Pendekatan dekolonisasi metodologi di tawarkan Linda Smith (2005) tentang perlunya membebaskan diri dari sandera kategori-kategori ilmiah yang dirumuskan dari Barat. Ilmu Pemerintahan yang digali dari kearifan lokal Indonesia adalah upaya dekolonisasi dan semangat pembebasan diri dari penjajahan keilmuan dari barat dengan pendekatan dekolonisasi. Perspektif yang dapat ditawarkan adalah liberasi dari pendekatan keilmuan dari barat, sehingga peneliti pribumi harus menempatkan penelitinya sebagai bagian kegiatan penyuaraan (advokasi) nilai-nilai pribumi. Pada akhirnya sampai kepada independensi (pribumisasi dan semangat pembebasan) keilmuan dalam kerangka berfikir yang terlepas dari kerangka berfikir dari barat. Di bawah ini dijelaskan Ilmu Pemerintahan sebagai upaya dekolonisasi (pribumisasi dan pembebasan keilmuan) melalui pendekatan Smith (2005) :

Tabel 3. Dekolonisasi Ilmu Pemerintahan

\begin{tabular}{|c|c|c|c|}
\hline \multirow{2}{*}{$\begin{array}{c}\text { Model } \\
\text { Pengembangan }\end{array}$} & \multicolumn{3}{|c|}{ Sisi Filosofis } \\
\hline & Ontologis & Epistemologis & Aksiologis \\
\hline Liberasi & $\begin{array}{c}\text { Digali dari } \\
\text { keotentikan } \\
\text { kearifan lokal }\end{array}$ & $\begin{array}{c}\text { Pengaturan } \\
\text { kepemimpinan } \\
\text { yang mandiri dan } \\
\text { autentik }\end{array}$ & $\begin{array}{l}\text { Kebebasan dari } \\
\text { pengaruh asing }\end{array}$ \\
\hline Advokasi & $\begin{array}{c}\text { Dekolonisasi Ilmu } \\
\text { Pemerintahan }\end{array}$ & $\begin{array}{l}\text { Kritik terhadap } \\
\text { dominasi } \\
\text { kolonialisme } \\
\text { keilmuan }\end{array}$ & $\begin{array}{l}\text { Penyuaraan hak- } \\
\text { hak pribumi }\end{array}$ \\
\hline Independensi & $\begin{array}{l}\text { Indigenous Ilmu } \\
\text { Pemerintahan }\end{array}$ & $\begin{array}{l}\text { Melepaskan diri } \\
\text { dari tersanderanya } \\
\text { kategori-kategori } \\
\text { keilmiahan }\end{array}$ & $\begin{array}{l}\text { Kemandirian dan } \\
\text { pribumisasi Ilmu } \\
\text { Pemerintahan }\end{array}$ \\
\hline
\end{tabular}

Sumber: diolah Peneliti \& Linda Smith, 2020

Pada tabel 3 dijelaskan tentang dekolonisasi Ilmu Pemerintahan adalah upaya transformatif semangat pembebasan dan kemandirian Ilmu Pemerintahan yang terlepas dari 
dominasi perspektif asing dari barat yang selama ini ada. Hail ini sekaligus juga menjelaskan ada perspektif dan pendekatan lain yang bisa menjelaskan problematika Ilmu Pemerintahan, dengan model pengembangan liberasi, advokasi, dan independensi Ilmu Pemerintahan keindonesiaan. Upaya menjadikan Indonesia sebagai isu utama dalam Ilmu Pemerintahan ini, tidak dapat diselesaikan dalam waktu yang singkat, akan tetapi akan memakan waktu puluhan tahun dan melibatkan beberapa generasi. Inilah pentingnya membangun tradisi peer-review berdasarkan gagasan pendahulunya. Ironisnya, misalnya, para sarjana Indonesia lebih fasih membahas gagasan Anthony Giddens daripada Arief Budiman, atau psikolog Indonesia lebih akrab dengan gagasan Sigmund Freud daripada Sutrisno Hadi. Dalam sejarah, negeri ini belum pernah kehabisan putra-putri terbaiknya, yang harusnya sudah sibuk dalam diskursus keilmuan keindonesiaannya (Agustinova, 2017).

Tradisi keilmuan pemerintahan Indonesia punya gagasan genuine (unik) misalnya, gagasan tentang budaya politik orang Bugis-Makassar, pamong praja dan birokrasi Jawa, bentuk pemerintahan Mataram Islam Indonesia, maupun konsep sederhana Pemerintahan Kerajaan Soppeng, dapat dijadikan alternatif pemikiran dan menggerakkan revolusi Ilmu Pemerintahan terutama revolusi Ilmu Pemerintahan. Revolusi Ilmu Pemerintahan senantiasa dimulai dan diinisiasi oleh minoritas kreatif lokal. Masyarakat lokal menjadi penanda bahwa mereka mempunyai "kekuatan" untuk membumikan Ilmu Pemerintahan model Indonesia yang mereka pahami.

Menggali dan memperkuat pengetahuan pemerintahan Indonesia akan memutus rantai pinjaman budaya keilmuan secara akademik. Masyarakat Indonesia tetap selalu terbuka dengan perkembangan dan kemajuan, Indonesia sangat khas dan punya diferensiasi, sehingga landasan budaya negaranya terus berakar pada jiwa masyarakat sebagai kearifan lokal (lokal wisdom). Maka kekayaan dalam khazanah keilmuan yang ada di Indonesia sangat cocok digunakan dalam menjawab problematika keindonesiaan khususnya dalam Ilmu Pemerintahan yang sebenarnya selama ini luput dilakukan para akademisi Ilmu Pemerintahan Indonesia yang lebih banyak menggunakan perspektif barat dalam menjawab problematika Ilmu Pemerintahan. Ilmuan Indonesia acapkali kurang percaya diri dalam diskursus keilmuan dan merujuk pada produk pengetahuan keilmuan nasional dalam perspektif kearifan lokal keilmiahan (keilmuan nusantara). Di sinilah para ilmuwan Indonesia perlu berubah (Setiawan, 2017). 
Tabel 4. Perbandingan Konsepsi Pemerintahan Indonesia dan Pemerintahan Asing

\begin{tabular}{|c|c|c|}
\hline Perihal & Pemerintahan Indonesia & $\begin{array}{c}\text { Pemerintahan Asing } \\
\text { (Versi Barat) }\end{array}$ \\
\hline $\begin{array}{l}\text { Kepemimpinan } \\
\text { Pemerintahan }\end{array}$ & $\begin{array}{c}\text { Kepemimpian keterwakilan } \\
\text { yang dianggap kompeten } \\
\text { dan berkapasitas untuk } \\
\text { mengatur hajat orang } \\
\text { banyak. }\end{array}$ & $\begin{array}{l}\text { Kepemimpian hasil Vote } \\
\text { (Suara Mayoritas) }\end{array}$ \\
\hline Kebijakan Pemerintahan & $\begin{array}{l}\text { Membangun kontrak politik } \\
\text { yang selalu di lafalkan oleh } \\
\text { pemimpin dan yang } \\
\text { dipimpin sebagai penjaga } \\
\text { nilai-nilai yang diyakini. }\end{array}$ & $\begin{array}{c}\text { Aturan sebagai hasil proses } \\
\text { produk benturan } \\
\text { kepentingan politik }\end{array}$ \\
\hline Birokrasi Pemerintahan & $\begin{array}{l}\text { Pagawai Publik sebagai } \\
\text { menjalankan kepentingan } \\
\text { masyarakat }\end{array}$ & $\begin{array}{l}\text { Pejabat Politik sebagai } \\
\text { penyelengaran } \\
\text { pemerintahan }\end{array}$ \\
\hline Politik Pemerinthan & $\begin{array}{c}\text { Kekuasaan dijalankan untuk } \\
\text { membangun tatanan } \\
\text { masyarakat bahagia dunai } \\
\text { akhirat }\end{array}$ & $\begin{array}{c}\text { Kekuasaan dijalankan untuk } \\
\text { menjaga ketertiban } \\
\text { masyarakat. }\end{array}$ \\
\hline
\end{tabular}

Sumber: diolah peneliti, 2020

Gambar 1. Bentuk-Bentuk Kolonialisasi Ilmu Pemerintahan \& Strategi

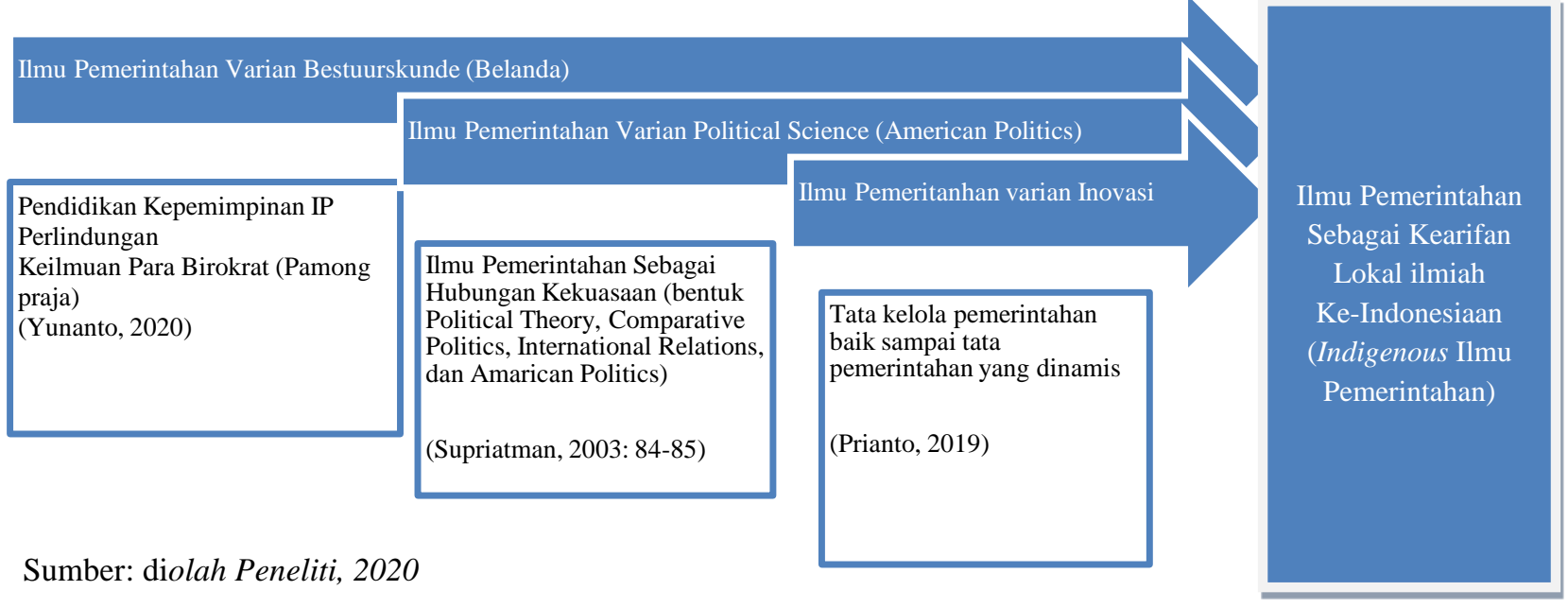

Ilmu Pemerintahan dalam diskursus pada pada tabel 4. dan upaya dekolonisasi dalam Gambar 1. melahirkan model pemerintahan yang berasal dari semangat (indigenous) kearifan lokal dan kekayaan khazanah keilmuan Ilmu Pemerintahan, yang digali dari praktik-praktik pemerintahan kerajan-kerajaan nusantara Indonesia. Pada bentuk perbandingan konsepsi Ilmu Pemerintahan keindonesiaan yang mengedepankan nilai-nilai leluhur yang bijaksana dibandingkan terkurung dalam semangat penaklukan bagi masyarakat Indonesia. Bentuk- 
bentuk kolonialisasi Ilmu Pemerintahan yang banyak mengadopsi bestuurskunde (Belanda) pendidikan para birokrat untuk memimpin pemerintahan di daerah-daerah dan American politics (Amerika) hubungan kekuasaan antara pemerintah dan yang diperintah (Supriatman, 2003: 82-83), sampai konsepsi good governance hingga tata kelola yang dinamis (Prianto \& Amalia, 2019: 28-41), harus dibebaskan. Karena Ilmu Pemerintahan bukan sekedar untuk melatih pejabat pemerintah atau untuk menginspirasi praktik-praktik pelayanan pemerintahan, tetapi juga untuk membangun budaya politik dan birokrasi yang berpijak pada realitas sosialnya

\section{INDEGENISASI SEBAGAI UPAYA TRANSFORMASI ILMU PEMERINTAHAN}

Menurut Ali Shariati (1996: 60), manusia sejati adalah orang yang memiliki tiga bakat utama, yaitu kesadaran, daya juang dan kreativitas. Orang-orang di tiga dimensi ini adalah mereka yang selalu berjuang melawan dan berusaha menyingkirkan kekuatan deterministik yang seringkali menyulitkan dan membatasi kesadaran diri, kemauan dan kreativitas mereka. Seseorang yang memiliki pemahaman penuh tentang dirinya dan masyarakatnya, maka dia dapat segera memahami realitas, dan kemudian dapat dan pada saat yang sama melaksanakan pembangunan dirinya dan masyarakatnya. Seperti yang dikatakan Alatas (2010: 77-78), dalam hal ini ilmuwan sosial Indonesia akan segera lepas dari apa yang disebut sebagai captive thinking. Pemikiran tawanan didefinisikan di sini sebagai pemikiran yang tidak tunduk pada peniruan kritis, didominasi oleh sumber-sumber eksternal, daripada perspektif independen.

Sejalan dengan pemikiran di atas, langkah terbaik yang diambil oleh para akademisi pribumi di Indonesia adalah dengan mengupayakan penggunaan realisme konstruktivis sebagai landasan filosofis dan mengusulkan sebuah strategi epistemologis. Ilmuwan sosial seperti akademisi Ilmu Pemerintahan dapat menggunakan realisme konstruktivis untuk membangun teori-teori ilmiah. Di dunia ketiga, terutama di Indonesia, dengan model hukum dan pemerintahan warisan dari kolonialisme, sudah harus meninggalkan model tersebut dan memulai sendiri kemandiriannya. Hal itu dapat dimulai dengan mendefenisikan kenyataan sebagai acuan untuk melakukan penelitian empiris tentang kehidupan masyarakatnya. 
Tabel 5. Fase Perkembangan Ilmu Pemerintahan

\begin{tabular}{|c|c|c|c|}
\hline \multicolumn{4}{|c|}{ Fase-Fase Perkembangan dalam Ilmu Pemerintahan } \\
\hline $\begin{array}{c}\text { Fase 1. Ilmu } \\
\text { Pemerintahan } \\
\text { Kolonial (indologie) }\end{array}$ & $\begin{array}{c}\text { Fase 2. Ilmu } \\
\text { Pemerintahan } \\
\text { developmentaslism }\end{array}$ & $\begin{array}{l}\text { Fase 3. Ilmu } \\
\text { Pemerintahan } \\
\text { Kontemporer }\end{array}$ & $\begin{array}{l}\text { Fase 4. Ilmu } \\
\text { Pemerintahan } \\
\text { Indogenous }\end{array}$ \\
\hline $\begin{array}{l}\text { Perkembangan keilmuan } \\
\text { pemerintah Indonesia } \\
\text { tidak terlepas dari } \\
\text { pemerintahan kolonial } \\
\text { Hindia Belanda di } \\
\text { Indonesia. Pada masa } \\
\text { inilah pemerintah Hindia } \\
\text { Belanda } \\
\text { memperkenalkan } \\
\text { pengaturan kepentingan } \\
\text { Hindia Belanda secara } \\
\text { lebih efektif yang } \\
\text { mempelajari semua jenis } \\
\text { pengetahuan pemerintah. } \\
\text { Hal itu kemudian } \\
\text { digunakan oleh Belanda } \\
\text { dimana banyak aspek } \\
\text { sistem pemerintahan } \\
\text { yang berlaku di Belanda } \\
\text { (biasanya mengikuti } \\
\text { sistem Perancis/ Jerman) } \\
\text { juga telah diterapkan di } \\
\text { Indonesia, yang } \\
\text { berdampak besar pada } \\
\text { penyelenggaraan } \\
\text { pemerintahan Indonesia } \\
\text { hingga hari ini. }\end{array}$ & $\begin{array}{l}\text { Selain itu, transformasi ini } \\
\text { juga terjadi melalui } \\
\text { penyebaran Ilmu } \\
\text { Pemerintahan dan budaya, } \\
\text { oleh karena itu } \\
\text { perkembangan Ilmu } \\
\text { Pemerintahan di Belanda } \\
\text { mulai dari era Kameralisme } \\
\text { (Jerman dan Perancis } \\
\text { menerapkan sistem / model } \\
\text { pemerintahan) hingga } \\
\text { lahirnya } \\
\text { bestuurswetenschap dan } \\
\text { bestuurswetenschappen } \\
\text { pada abad ke-20. } \\
\text { Perkembangan ide memiliki } \\
\text { dampak yang besar. } \\
\text { Pemikiran tentang } \\
\text { pemerintahan Indonesia. } \\
\text { Setelah menjadi negara } \\
\text { merdeka, Indonesia telah } \\
\text { dipengaruhi oleh sistem } \\
\text { pemerintahan Inggris dan } \\
\text { Amerika serta oleh } \\
\text { perkembangan ilmiah } \\
\text { administrasi publik. }\end{array}$ & $\begin{array}{l}\text { Diciptakan sebuah asas } \\
\text { yang disebut dengan asas } \\
\text { dekonsentrasi, yang } \\
\text { pelaksanaanya } \\
\text { dipercayakan kepada } \\
\text { suatu korps pegawai } \\
\text { khusus yaitu } \\
\text { Binnenlandsch Bestuur } \\
\text { scorps, yang kemudian } \\
\text { dialih-bahasakan kedalam } \\
\text { Bahasa Indonesia menjadi } \\
\text { "Pangrehpraja" dan } \\
\text { semenjak Indonesia } \\
\text { merdeka kemudian } \\
\text { berubah menjadi } \\
\text { "Pamongpraja". Setelah } \\
\text { proklamasi kemerdekaan, } \\
\text { Korps Pamongpraja ikut } \\
\text { serta secara aktif dalam } \\
\text { usaha mewujudkan sistem } \\
\text { pemerintahan dari Negara } \\
\text { Kesatuan Republik } \\
\text { Indonesia yang } \\
\text { berdasarkan Pancasila. }\end{array}$ & $\begin{array}{l}\text { Pemerintahan Lokal } \\
\text { dan kearifan lokal } \\
\text { (lokal wisdom) } \\
\text { keindonesiaan dalam } \\
\text { semangat dekolonisas } \\
\text { dan indegenesasi Ilmu } \\
\text { Pemerintahan } \\
\text {-dekonstruksi } \\
\text {-rekonstruksi } \\
\text {-transformasi } \\
\text { Sampai pada } \\
\text { Dekolonisasi } \\
\text { Indigenous Ilmu } \\
\text { Pemerintahan }\end{array}$ \\
\hline
\end{tabular}

Sumber: diolah dari Gafar dan Jamil, $2018: 176-200$

Pada tabel 5 di atas menjelaskan Ilmu Pemerintahan sebagai ilmu yang mandiri mengacu dalam perkembangannya sebagai ilmu dengan empat pembagian fase perkembangan yakni Ilmu Pemerintahan kolonial (indologie), Ilmu Pemerintahan developmentaslism, dan Ilmu Pemerintahan kontemporer, dan terakhir fase indegenisasi Ilmu Pemerintahan yaitu perkembangan Ilmu Pemerintahan yang berbasis kearifan lokal (lokal wisdom) keindonesiaan. Strategi dekolonisasi dan indegenisasi Ilmu Pemerintahan ini melalui jalur dekonstruksi, rekonstruksi dan transformasi kepada kearifan lokal ilmiah keindonesiaan, yang tidak ada di belahan bumi manapun. Minimnya perkembangan ilmuilmu sosial di Indonesia, membuat diskursus dekonstruksi, rekonstruksi dan transformasi Ilmu Pemerintahan seperti kehilangan arena. Solusi dan formula yang ada di Lembaga akademik tidak relevan lagi karena tidak sejalan dengan kehidupan nyata yang menuntut 
ketepatan, kesesuaian, dan solutif/kontributif bagi permasalahan-permasalahan pemerintahan yang ada. Semangat kolonisasi dan dekolonisasi ini akan menjadikan perguruan tinggi Indonesia tidak hanya menjadi pasar dan konsumen produk pendidikan luar negeri. Akibatnya, perguruan tinggi di Indonesia dalam produksi dan reproduksi kearifan ilmiahnya (scientific knowledge), namun penuh kebanggaan pada impor pengetahuan.

Pemahaman yang baik tentang kearifan lokal, sebagai khazanah keilmuan baru yang dinamis dan kompleks semakin dibutuhkan. Menurut Sunyoto Usman (2004), faktanya tidak semua Ilmu Pemerintahan dan metodologi yang dikembangkan Barat, dapat digunakan untuk memahami situasi di Indonesia. Misalnya, soal pemilihan dan penunjukan kepala wilayah, yang dalam teori-teori Barat tidak memasukkan unsur koneksi primordial (kearifan lokal). Di Indonesia, masih sangat sulit untuk menentukan orang untuk menjadi pemimpin daerah. Demikian pula, kondisi sosial politik sangat berbeda dengan negara-negara Barat. Dalam situasi stagnasi dan sesat-pikir pengembangan Ilmu Pemerintahan, studi-studi di skala terbatas yang telah dilakukan lebih dominan dari sisi ontologis, tidak diimbangi dengan kepiawaian epistemologis. Disamping itu ilmu tidak berkembang karena secara aksiologis ilmu dipelajari sekedar untuk tahu lebih banyak (P. Santoso, 2012).

Tabel 6. Peta Filosofis Pengembangan Ilmu Pemerintahan

\begin{tabular}{|c|c|c|c|}
\hline $\begin{array}{c}\text { Model } \\
\text { Pengembangan }\end{array}$ & Ontologis & Epistemologis & Aksiologis \\
\cline { 2 - 4 } Sintaktik & Kemauan masyarakat & Mengatur masyarkat & $\begin{array}{c}\text { pendistribusi } \\
\text { kebahagiaan secara } \\
\text { adil }\end{array}$ \\
\hline Semantik & $\begin{array}{c}\text { Eksistensisnya sebagai } \\
\text { keniscayaan di tengah } \\
\text { kompleksitas }\end{array}$ & Pengendali konflik & $\begin{array}{c}\text { Alat untuk } \\
\text { mewujudkan } \\
\text { kebaikan Bersama }\end{array}$ \\
\hline Transformatif & $\begin{array}{c}\text { Pemerintahan sebagai } \\
\text { lembaga kepemimpinan } \\
\text { profetik dengan misi } \\
\text { ketuhanan }\end{array}$ & $\begin{array}{c}\text { Pemerintahan sebagai } \\
\text { abdi masyarakat dalam } \\
\text { rangka tugas wakil Tuhan } \\
\text { dibumi. }\end{array}$ & $\begin{array}{c}\text { Kebahagian dunia } \\
\text { akhir untuk sekalian } \\
\text { manusia. }\end{array}$ \\
\hline
\end{tabular}

Sumber: olahan peneliti dari Santoso (2012)

Pada tabel 6 Penguasaan epistemologi memungkinkan ilmuwan untuk memahami berbagai pemahaman tentang berbagai hal. Termasuk tentang keberadaan berbagai hal memungkinkannya untuk menggambarkan makna. Kemampuan mengejar pemahaman paradigma dengan memperkuat landasan epistemologis memungkinkan para ilmuwan untuk mengembangkan pembelajaran pada tingkat lebih tinggi. Kembali ke contoh sebelumnya: 
sistem pembelajaran. Tujuannya tidak hanya bagaimana mereproduksi cara berpikir sistematis, tetapi juga ketika isu paradigma diangkat karena isu aksiologis, maka perkembangan ilmu transformasional juga akan terarah. Saat mempelajari sistem dan pemikiran sistem, belajar didasarkan pada keinginan untuk membentuk sistem dalam situasi tertentu. Hal itu menjadi tuntutan yang kuat (pekerjaan yang besar) untuk menyelesaikan masalah gejala keilmuan yang membutuhkan kerangka kerja epistemologis yang baik untuk menjelaskannya (P. Santoso, 2012).

Ilmu Pemerintahan transformatif yakni ilmu yang tidak hanya punya peringkat "menara gading", apalagi hanya diperlakukan sebagai mesin reproduksi birokrasi, namun juga sebagai suatu diskursus yang memberikan kontribusi kritis, agendatif dan praksis terhadap perubahan governance menuju demokrasi dan keadilan sosial. Perspektif transformasi (Eko, 2003: 78-81), berarti membangun sebuah Ilmu Pemerintahan transformatif, melalui cara: Pertama, Ilmu Pemerintahan transformatif berupaya menggeser perhatian kajian dari perilaku aktor pemerintah di tingkat nasional menjadi kajian pada masyarakat lokal. Melihat bagaimana demokrasi, otonomi daerah, serta pembangunan berkelanjutan akan jauh lebih kokoh dan bermakna, bila diletakkan (berbasis) pada konteks kemitraan dan partisipasi masyarakat lokal, bukan pada konteks persaingan-kompetisi aktoraktor pemerintah. Kedua, Ilmu Pemerintahan transformatif lebih mengedepankan pembelajaran etika dan komitmen politik tentang bagaimana menggunakan kekuasaan dibanding mempelajari pertarungan aktor-aktor pemerintah dalam mencari dan mempertahankan kekuasaan. Perhatian utama political studies pada kompetisi justru akan melahirkan persepsi publik bahwa Ilmu Pemerintahan yakni ilmu yang mereproduksi kekuasaan ketimbang etika dan memberikan justifikasi bagi pertarungan kekuasaan, yang sedikit-banyak menimbulkan anti-politik. Ketiga, Ilmu Pemerintahan transformatif mengambil fokus pada lokal governance, dengan mengedepankan kajian pada sisi civil society daripada kajian reproduksi birokrasi, regulasi, otoritas, legalitas, dan lainnya. Kebijakan dan regulasi memang sangat penting dalam pemerintahan, tetapi yang lebih penting adalah bagaimana konteks, konten dan proses diletakkan dalam arena civil society, bukan dikelola secara teknokratis-birokratis. Keempat, Ilmu Pemerintahan pada metodologi transformatifnya berupaya melewati hegemoni positivisme, yang selama ini mengungkung ilmu politik. Melalui pendekatan humanistik dan kritis, Ilmu Pemerintahan transformatif 
mengupayakan membongkar teori-teori yang sudah lama dan mapan dalam belantara ilmu politik. Meninggalkan konsepsi-konsepsi keilmuan Barat, seraya membangun teori-teori preskriptif yang berbasis pada konteks kearifan lokal (keindonesiaan). Ilmu Pemerintahan bukan lagi pengimpor teori-teori asing yang tidak relevan, melainkan menggali teori dari khazanah kearifan lokal keindonesiaan melalui pendekatan induktif-empirik.

Pada akhirnya akan mereproduksi model indigenous Ilmu Pemerintahan yang disebut Ilmu Pemerintahan Indonesia (governmental science of Indonesia) yang mandiri dan terlepas dari kolonisasi akademis dan praktis. Ilmu Pemeritahan yang mandiri akan mendorong kebijakan pemerintahan keindonesiaan yang berbasis kearifan lokal. Seperti budaya politik pemerintahan Indonesia dengan kearifan lokalnya yang penuh semangat dalam perjuangan kolektif. Karena dalam sistem pemerintahan yang baik, terdapat sistem organisasi pemerintahan yang mampu menjawab suatu masalah dengan menjalankan tugas, peran dan fungsinya secara baik dan benar (Abdillah et al., 2020). Sebagaimana pemerintahan yang baik adalah pemerintahan yang berpihak pada mereka yang lemah dan tertindas.

\section{KESIMPULAN}

Ilmu Pemerintahan adalah diskursus keilmuan di Indonesia yang unik dan yang tidak dikenal di belahan dunia lain. Tetapi Ilmu Pemerintahan selalu tunduk pada rangsangan eksternal: kolonialisme, developmentalisme, dan neoliberalisme. Alasan mengapa dia hadir adalah karena keniscayaan gejala pemerintahan dalam suatu negara membutuhkan konsep nilai yang filosofis dan pragmatis untuk menjelas masalah yang dihadapinya secara tepat sehingga dapat dirumuskan solusi untuk menghadapinya. Hal itulah yang akan membuatnya terus bertahan. Dengan Ilmu Pemerintahan keindonesiaan berbasis kearifan lokal menjadi perspektif baru dalam menjawab problematika di dalam fenomena pemerintahan yang tidak mampu dijelaskan oleh keilmuan lain selain Ilmu Pemerintahan. Dekolonisasi dan indigenisasi Ilmu Pemerintahan sebagai persketif baru dalam semangat pembebasan. Perspektif baru ini melihat Ilmu Pemerintahan yang bukan sekedar untuk melatih pejabat pemerintah atau untuk menginspirasi praktik-praktik pelayanan pemerintahan, tetapi juga untuk membangun budaya politik dan birokrasi yang berpijak pada realitas sosialnya. Sebagaimana pemerintahan yang baik adalah pemerintahan yang berpihak pada mereka yang lemah dan tertindas. 


\section{DAFTAR PUSTAKA}

Abdillah, D., N. A., Yuningsih, N. Y., \& Fatmawati. 2020. The Position of Auxiliary Organ in Government System of West Java Provincial Government. Journal of Contemporary Governance and Public Policy, 1(2), 67-81. https://doi.org/https://doi.org/10.46507/jcgpp.v1i2.11

Abdullah, T. 1984. Ilmu Sosial dan Realitas Indonesia dalam Prisma, 9 tahun 1984. LP3ES.

Agustinova, D. E. 2017. Meneguhkan ilmu sosial keindonesiaan: Indegeneousisasi Ilmu Sejarah. FIS-UNY.

Alatas, S. F. 2010. Diskursus Alternatif dalam Ilmu Sosial Asia. Mizan Publika.

Amalinda Savirani. 2003. Ilmu Pemerintahan Masa Depan: Mengadvokasi politik pinggiran. $1(1), 62-76$.

Apter, D. 1965. Comparative Politics. The Free Press.

Ashcroft, B., Griffiths, G., \& Tiffin, H. 2007. POST-COLONIAL STUDIES; The Key Concepts Second edition. Routledge.

Creswell, J. W. 2012. METODE PENELITIAN KUALITATIF (pp. 1-678). Pustaka Pelajar.

Cynthia, M., \& Bautista, R. B. 1997. Filipina: Refleksi tentang Perkembangan Ilmu Sosial”, dalam Nico Schutle $N$ dan Leontine Visser, Ilmu Sosial Di Asia Tenggara: Dari Partikularisme ke Universalisme. LP3ES.

Denhardt, R. B., \& Denhardt, J. V. 2003. The new public service: Serving rather than steering. In Public Administration Review. M.E. Shape. https://doi.org/10.1111/00333352.00117

Djati, W. R. 2013. Revivalisme Kekuatan Familisme dalam Demokrasi: Dinasti Politik di Aras Lokal. Jurnal Sosiologi Masyarakat, 18, 203-231. https://doi.org/https://doi/org/10.7454/mjs.v18i2.3726

Eko, S. 2003. Ilmu Pemerintahan transformatif. 1(September), 78-81.

Foucault, M. 2011. The Government of Self and Others, Palgrave Macmillan. In Foucault Studies. Palgrave Macmillan. https://doi.org/10.22439/fs.v0i10.3127

Haboddin, M., Sulaksono, T., Yanuardi, Bayo, L. N., Mubarak, A. H., \& Priyahita, W. 2016. Metodologi Ilmu Pemerintahan. (M. Haboddin (ed.)). Pusat Kajian Inovasi Pemerintahan dan Kerjasama AntarDaerah.

Harun, M. Y. 1994. Kerajaan Islam Nusantara Abad XVI \& VII. Kunia Kalam Sejahtera.

Hastuti. 2017. "Merajut Ilmu Sosial Keindonesiaan Melalui Penelitian Kearifan Lokal" di 
dalam “meneguhkan ilmu sosial keindonesiaan.” FIS-UNY.

Iver, M. 1947. The Web of Government. In Thought. Macmillan Co. https://doi.org/10.5840/thought1947223148

Kila, S., Sahajuddin, \& Amir, M. 2018. Soppeng: dari Tomanurung hingga Penjajahan Belanda. In Physica (Vol. 25). Pustaka Refleksi.

KuntjoroJakti, D. 1984. Cendekiawan Dunia Ketiga: Orang "Barat” di Dunia "Timur”, dalam Aswab Mahasin dan Ismed Natsir (Peny.), Cendekiwan dan Politik Sosial. LP3ES.

Labolo, M. 2013. Memahami Ilmu Pemerintahan: Suatu Kajian, Teori, Konsep, dan Pengembangannya. In Ilmu Pemerintahan. Pajagrafiindo Persada.

Langill, S., \& Landon, S. 1998. Indigenous Knowledge. IDRC-Lib. https://doi.org/10.4324/9781315612744

Poelje, V. G. A. 1953. Pengantar Umum Ilmu Pemerintahan. In Terj. Djakarta: NV Soeroengan 58.

Prianto, A. L. 2011. Good governance dan formasi kebijakan publik neo-liberal. 1(1), 1-10.

Prianto, A. L. 2014. Model of Advocacy Coalitions in the Formulation of Spatial Plan Policy of Makassar in 2010-2030. Bisnis \& Birokrasi Journal, 20(3). https://doi.org/10.20476/jbb.v20i3.3205

Prianto, A. L., \& Amalia, A. A. 2019. Combatting Slums, Suistaining Poverty: Dynamic Urban Governance in Makassar, Indonesia. Otoritas : Jurnal Ilmu Pemerintahan, 9(1), 28-41. https://doi.org/10.26618/ojip.v9i1.2008

Santoso, H., \& Santoso, L. 2003. Filsafat Ilmu Sosial, Ikhtiar Awal Pribumisasi Ilmu Sosial di Indonesia. Gama Media.

Santoso, P. 2012. Ilmu Sosial Transformatif. Millah, XI(2 Februari 2012), 608-632. https://doi.org/10.20885/millah.volxi.iss2.art13

Setiawan, B. 2017. "Merdeka dari Ilmu Sosial" di dalam "meneguhkan ilmu sosial keindonesiaan". FIS-UNY.

Smith, L. T. 2005. Dekolonisasi Metodologi. In e-conversion - Proposal for a Cluster of Excellence (pp. 1-9). Insist Press.

Soedjatmoko. 1980. “Dimensi-Dimensi Struktural Kemiskinan”, dalam Alfian dkk (Ed.). "Kemiskinan Struktural Suatu Bunga Rampai." Yayasan Ilmu Ilmu Sosial.

Sudrajat, A., \& Nasiwan. 2017. "Tapak-Tapak Kecil Indigenisasi Ilmu-Ilmu Sosial: Pengalaman Membangun Diskursus Alternatif di Fakultas Ilmu Sosial” di dalam "meneguhkan ilmu sosial keindonesiaan". FIS-UNY. 
Supriatman, M. T. 2003. Ilmu Pemerintahan: Menciptakan Bestuur atau Political Scientist? 1 (1, september), 82-85.

Sutherland, H. 1979. The Making of Bureaucratic Elite: The Colonial Transformation of the Javanese Priyayi. Heineman Educational Books (Asian Studies Association of Australia).

Syariati, A. 1996. Tugas Cendikiawan Muskim. Srigunting.

Usman, S. 2004. Sosiologi: Sejarah, Teori, dan Metodologi. Cired.

Wilson, W. 1903. The State. Harper \& brothers.

Yani, A. A. 2007. Budaya Politik Orang Bugis dalam Dinamika Politik Lokal. Jurnal Masyarakat Dan Budaya, 9(2), 105-122.

Yunanto, S. E. 2020. Ilmu Pemerintahan: Anti Pada Politik, Lupa Pada Hukum, dan Enggan Pada Administrasi. Governabilitas, 1(1), 1-23. https://doi.org/10.1155/2010/706872 